\title{
Nest architecture of the stingless bee Geotrigona subterranea (Friese,1901) (Hymenoptera: Apidae: Meliponini)
}

\author{
Fernando Mendes Barbosa ${ }^{1,5}$, Rogério Marcos de Oliveira Alves ${ }^{2}$, \\ Bruno de Almeida Souza ${ }^{3}$ \& Carlos Alfredo Lopes de Carvalho 4 \\ ${ }^{1}$ Setor de Zootecnia I, Instituto Federal de Educação, \\ Ciência e Tecnologia do Norte de Minas Gerais - IFNMG, Fazenda São Geraldo, Km 06, \\ CEP 39480-000, Januária, MG, Brasil \\ ${ }^{2}$ Grupo de Pesquisa Insecta, Instituto Federal de Educação, Ciência e Tecnologia Baiano - IF Baiano, \\ CEP 41720-052, Salvador, BA, Brasil \\ ${ }^{3}$ Embrapa Semi-Árido, BR 428, Km 152, Zona Rural, CP 23, CEP 56302-970, Petrolina, PE, Brasil \\ ${ }^{4}$ Grupo de Pesquisa Insecta, Centro de Ciências Agrárias, Ambientais e Biológicas, \\ Universidade Federal do Recôncavo da Bahia - UFRB, CEP 44380-000, Cruz das Almas, BA, Brasil \\ ${ }^{5}$ Corresponding author: Fernando Mendes Barbosa, e-mail: fernando.barbosa@ifnmg.edu.br
}

BARBOSA, F.M., ALVES, R.M.O., SOUZA, B.A. \& CARVALHO, C.A.L. Nest architecture of the stingless bee Geotrigona subterranea (Friese,1901) (Hymenoptera: Apidae: Meliponini). Biota Neotrop. 13(1): http:// www.biotaneotropica.org.br/v13n1/en/abstract?article+bn03913012013

Abstract: We located ten nests of Geotrigona subterranea in the transition area between Cerrado and Caatinga within the municipalities of Lontra and Januária, state of Minas Gerais, southeastern Brazil. We collected the nests to study their architecture in detail. In the present paper, we describe the general nest structure of this bee species in terms of: number, shape and area of the combs; size of the brood cells; size of honey and pollen pots; volume of honey and mass of pollen stored in closed pots; presence of inquiline species; and defensive characteristics. All nests were found in subterranean cavities. The nest structure of G. subterranea is similar to that of other congeneric species.

Keywords: bionomy, nesting, stingless bee, mombuca bee.

BARBosA, F.M., ALVES, R.M.O., SOUZA, B.A. \& CARVALHO, C.A.L. Arquitetura do ninho de Geotrigona subterranea (Friese, 1901)(Hymenoptera: Apidae: Meliponini). Biota Neotrop. 13(1): http://www. biotaneotropica.org.br/v13n1/pt/abstract?article+bn03913012013

Resumo: Foram localizados dez ninhos de Geotrigona subterranea em áreas de transição entre o Cerrado e a Caatinga nos municípios de Lontra e Januária, Estado de Minas Gerais. Os ninhos foram coletados para observação da arquitetura. Neste trabalho são apresentadas informações sobre estrutura geral e forma do ninho desta espécie; número, forma e área dos favos de cria; tamanho de células de cria; tamanho de potes de mel e pólen; volume dos potes de mel e massa de pólen em potes fechados; presença de inquilinos e características de defesa. Todos os ninhos foram encontrados em cavidades subterrâneas. De modo geral, esta espécie apresenta estrutura de ninho similar a apresentada por outras espécies do mesmo gênero.

Palavras-chave: bionomia, nidificação, abelha sem ferrão, abelha Mombuca. 


\section{Introduction}

Stingless bees (Meliponini) are found in tropical and subtropical regions of the world (Michener 2007); 33 genera are exclusively Neotropical (Camargo \& Pedro 2012). The genus Geotrigona is broadly distributed in the Neotropics; it occurs from Michoacán, Mexico, to Santiago del Estero, northern Argentina (Camargo \& Moure 1996, Gonzalez \& Sepúlveda 2007), and comprises 22 species (Camargo \& Pedro 2012, Gonzalez \& Engel 2012). G. subterranea (Friese, 1901) occurs in the Brazilian states of Bahia, Minas Gerais, Paraná, and São Paulo (Camargo \& Moure 1996, Silveira et al. 2002). This bee species is locally known as mombuca, guiruçu, or guiruçu mineiro, depending on the region. Its nests are found in underground cavities, which are usually abandoned chambers built by leafcutter ants.

Meliponini bees build their nests in several substrates, such as subterranean cavities, tree trunks, branches of living trees, rock crevices, brick walls, active or abandoned termite nests, arboreal ant nests, subterranean chambers abandoned by ants, active bird nests, or empty nests attached to branches (Schwarz 1948, Camargo 1970, Wille 1983, Campos 1987, Kerr et al. 1996, Roubik 2006).

The materials used for nest building are mainly pure wax or cerumen - a mixture of wax and propolis - resins, plant fibers, and clay (Rasmussen \& Camargo 2008). Camargo (1970) considers the nesting site as the main limiting factor for population growth in stingless bees.

Currently, due to the accelerated destruction of forests, environmentalists have developed conservation programs for plant and animal species. In terms of restoration and preservation of the native flora, pollination is an important phenomenon that must be assessed. Studies on the biology of pollinating bees, issues related to their maintenance in artificial nests, and their reproduction and division of colonies are important for conservation (Kerr et al. 1996).

The nesting biology of $G$. subterranea was briefly described by Camargo \& Moure (1996). A detailed description of the nest architecture of G. mombuca was made by Nogueira-Neto \& Sakagami (1966). However, no description is available for G. subterranea yet.

The present study describes the nest structure of G. subterranea, and provides important information for the management of colonies and species conservation.

\section{Materials and Methods}

The present study was carried out in Lontra ( $15^{\circ} 54^{\prime} 10^{\prime} \mathrm{S}$, $44^{\circ} 18$ ' 18” W, $781 \mathrm{~m}$ a.s.l.) and Januária (15 ²9’ 16” S, 44²1' 43” W; $554 \mathrm{~m}$ a.s.l.), state of Minas Gerais, southeastern Brazil. The vegetation in the region is characterized as a transition between Cerrado and Caatinga. The regional climate is Aw according to the Köppen system, and is characterized by a dry winter and a rainy summer.

We excavated and collected ten nests between November 2010 and August 2011 to analyze their external and internal structure, as well as other characteristics. The nests were numbered from 01 to 10. The description of nests followed Wille \& Michener (1973), as presented by Souza et al. (2008).

We cleaned the surroundings of each nest, measured the diameter of the entrance, and excavated laterally to reach the nest. We measured the external part of the active cavity and its depth with a measuring tape. In some cases, we estimated the length of the entrance channel.

We estimated the space occupied by the brood based on the height and diameter of the combs. We counted honey and pollen pots, and measured their height and diameter with a caliper. We measured the volume of the honey pots using a $20-\mathrm{mL}$ graduated syringe to completely withdraw the contents. We weighed the mass of pollen in closed pots with analytic scales.

We estimated the population size with the equation $(X+X / 2)$, in which $\mathrm{X}$ represents the total number of cells obtained, following Aidar (1996).

The collected specimens were sent to the Department of Biology, Faculdade de Filosofia, Ciências e Letras de Ribeirão Preto, Universidade de São Paulo, for identification.

\section{Results}

\section{Nesting site}

All nests were built in underground cavities. The nests 01, 02, 07, 09, and 10 were built in abandoned ant nests; the nests 04 and 05 were found in inactive nests of subterranean termites; the nest 08 was found in a simple cavity between the ground and a masonry structure; the nests 03 and 06 were found in chambers formed by rainwater. Data on nest architecture are presented in Table 1.

Among the nests studied, two were located in shaded areas with dense vegetation and the others in sunny areas, which were clean or covered with undergrowth. The excavated nests were found in soils with different physical properties, especially in terms of texture.

\section{Nest architecture}

\subsection{Nest entrance}

The entrance hole is circular with a diameter that ranges from $0.85 \mathrm{~cm}$ to $1.20 \mathrm{~cm}$ and an average value of $1.0 \mathrm{~cm}$. In all nests, we observed detritus around the entrance, composed of particles of clay, gravel, leaves, sticks, and sawdust in a pile reaching up to $14 \mathrm{~cm}$ (Figure 1). The height of the pile of waste varied among environments; it was higher in areas where the humus layer was thicker. In periods of high rainfall, the deposit of sticks also increased. The entrance was guarded by three to four workers during the day.

\subsection{Channel to the nest cavity}

The length of the access tunnel depended on nest depth and shape of the duct. We observed almost straight tunnels, with very slight curves as well as S-shaped tunnels. The diameter varied from $1.7 \mathrm{~cm}$ to $2.7 \mathrm{~cm}$, with an average value of 2.5. In general, the tunnel was coated with a thin layer of cerumen and opened into the upper region of the nest (Figure 1).

\subsection{Nest cavity}

As described above, the nests were found in several types of cavities. The studied nests did not occupy the cavities completely, but were built on top of the cavities, leaning on the side walls through slight evaginations of the outer involucrum. These characteristics are represented by values of cavity and nest volume in Table 1 ; the cavity had higher volume than the nest.

\subsection{Nest}

The nest shape varied. In most cases the width was greater at the top and decreased until it reached the bottom. Oval-shaped nests were observed.

The nest was externally covered by a cerumen layer. i.e., the outer involucrum, and internally it contained a layer of food pots, several layers of internal involucrum, and the brood area.

\subsection{Outer involucrum}

It consisted of a cerumen layer of brittle consistency and dark color (Figure 1d), which formed light evaginations to bind it to the 
Table 1. Data of 10 nests of Geotrigona subterranea collected in Lontra and Januária, state of Minas Gerais, southeastern Brazil.

\begin{tabular}{|c|c|c|c|c|}
\hline Variable & $\mathbf{n}$ & Unit & Range & Mean \pm SD \\
\hline Chamber length & 10 & $\mathrm{~cm}$ & $18.5-70.0$ & $38.15 \pm 14.92$ \\
\hline Chamber width & 10 & $\mathrm{~cm}$ & $14.5-41.0$ & $29.95 \pm 8.93$ \\
\hline Chamber height & 10 & $\mathrm{~cm}$ & $21.0-70.0$ & $29.75 \pm 14.44$ \\
\hline Chamber volume & 10 & $\mathrm{~L}$ & 7.8-92.6 & $36.64 \pm 26.75$ \\
\hline Nest length & 10 & $\mathrm{~cm}$ & $17.0-36.0$ & $25.59 \pm 6.31$ \\
\hline Nest width & 10 & $\mathrm{~cm}$ & $13.0-26.6$ & $19.66 \pm 4.76$ \\
\hline Nest height & 10 & $\mathrm{~cm}$ & $14.0-28.0$ & $17.92 \pm 4.42$ \\
\hline Nest volume & 10 & $\mathrm{~L}$ & $3.43-15.22$ & $9.27 \pm 4.03$ \\
\hline Diameter of the brood area & 10 & $\mathrm{~cm}$ & $7.2-11.9$ & $9.91 \pm 1.40$ \\
\hline Height of the brood area & 10 & $\mathrm{~cm}$ & 7.9-15.0 & $11.79 \pm 2.28$ \\
\hline Volume of the brood area & 10 & $\mathrm{~L}$ & $0.32-1.43$ & $0.95 \pm 0.35$ \\
\hline Nest depth & 10 & $\mathrm{~cm}$ & $39.0-222.0$ & $119.40 \pm 59.02$ \\
\hline Diameter of the nest entrance & 10 & $\mathrm{~cm}$ & $0.8-1.2$ & $0.96 \pm 0.14$ \\
\hline Number of brood combs & 10 & un. & $8.0-13.0$ & $11.10 \pm 1.91$ \\
\hline Diameter of brood combs & 110 & $\mathrm{~cm}$ & $2.60-11.50$ & $7.67 \pm 1.84$ \\
\hline Number of cells/cm² in brood combs & 10 & un. & $9.168-9.427$ & $9.275 \pm 0.08$ \\
\hline Height of brood cells & 130 & $\mathrm{~mm}$ & $5.79-6.73$ & $6.13 \pm 0.18$ \\
\hline Diameter of brood cells & 130 & $\mathrm{~mm}$ & $3.36-4.46$ & $4.00 \pm 0.20$ \\
\hline Pillar thickness & 115 & $\mathrm{~mm}$ & $0.90-2.98$ & $1.80 \pm 0.44$ \\
\hline Pillar height & 117 & $\mathrm{~mm}$ & 2.35-3.96 & $3.20 \pm 0.33$ \\
\hline Height of the honey pot & 151 & $\mathrm{~cm}$ & 2.36-7.36 & $5.27 \pm 1.04$ \\
\hline Diameter of the honey pot & 151 & $\mathrm{~cm}$ & $1.14-2.34$ & $1.50 \pm 0.16$ \\
\hline Volume of the honey pot & 119 & $\mathrm{~mL}$ & $1.80-11.00$ & $6.82 \pm 1.99$ \\
\hline Height of the pollen pot & 141 & $\mathrm{~cm}$ & $2.25-7.51$ & $5.26 \pm 0.96$ \\
\hline Diameter of the pollen pot & 141 & $\mathrm{~cm}$ & $1.13-1.78$ & $1.45 \pm 0.13$ \\
\hline Pollen deposited in closed pots & 93 & g & $2.50-14.91$ & $7.04 \pm 2.60$ \\
\hline Population size & 10 & un. & 2726-11074 & $7484.90 \pm 2171.77$ \\
\hline
\end{tabular}

$\mathrm{n}=$ number of units assessed.

side walls of the underground cavity. This envelope has the function of separating the nest from the wall of the cavity.

\subsection{Storage pots}

Storage pots were located between the inner and outer involucrum. They formed a solid mass around the brood area and, in some cases, on the top of the nest. We found no differences in location and size between honey and pollen pots. The shape of the pots was cylindrical and slightly oval at the extremities (Figure 1d). The outer walls of the pots were thick and black; the walls between pots were thin and sometimes they broke, connecting one pot to the other. We observed honey and pollen in the same pot in some cases. We observed pots containing crystallized honey in three nests. The honey had a slightly sour taste and the average volume was $500 \mathrm{~mL} /$ colony. The average mass of pollen stored was $250 \mathrm{~g} /$ colony.

\subsection{Inner involucrum}

This structure was observed in all nests. It consisted of 4-6 layers of cerumen, $1 \mathrm{~cm}$ apart from each other, with colors ranging from light brown to black. Unlike the outer involucrum, it was soft. On the outer layers, small resin deposits were built.

\subsection{Brood area}

The height of the brood area varied from 7.9 to $13.0 \mathrm{~cm}$ and the diameter from 7.2 to $11.9 \mathrm{~cm}$. It consisted of complete spiral combs arranged horizontally (Figure 1c). Comb diameter varied from 2.6 to $11.5 \mathrm{~cm}$, with an average value of $7.67 \mathrm{~cm}$. The number of brood combs varied from 8 to 13. The average distance between combs was $3.2 \mathrm{~mm}$. Combs were supported by many pillars, with thickness varying from 0.90 to $2.98 \mathrm{~mm}$. The volume of the brood area volume varied from 0.32 to $1.43 \mathrm{~L}$, with an average value of $0.95 \mathrm{~L}$.

Brood cells had an average height of $6 \mathrm{~mm}$ and an average diameter of $4 \mathrm{~mm}$. The height of one royal cell was $9.8 \mathrm{~mm}$ and its diameter was $5.8 \mathrm{~mm}$. Royal cells are built at the extremities of the combs. We observed that several brood cells were constructed at the same time; we found from 5 to 12 cells at several growth stages in the same comb (Figure 1c).

\subsection{Drainage canal}

Despite being a common structure in the nests of ground-nesting bees, whose function is to drain the excess of moisture, we did not observe the presence of any draining canal in the studied nests.

\subsection{Resin deposits}

On the layers of the inner involucrum small deposits of darkcolored resin were built. The outermost layer of deposit, which contacts the colony environment, had a hard consistency and a sticky interior. The shape of the deposits was not clearly defined, and it was often irregular.

\subsection{Garbage}

In the free space between the nest and the cavity bottom, we detected the presence of dead bees and other decomposing materials, possibly discarded by workers. In this place, we also detected other 

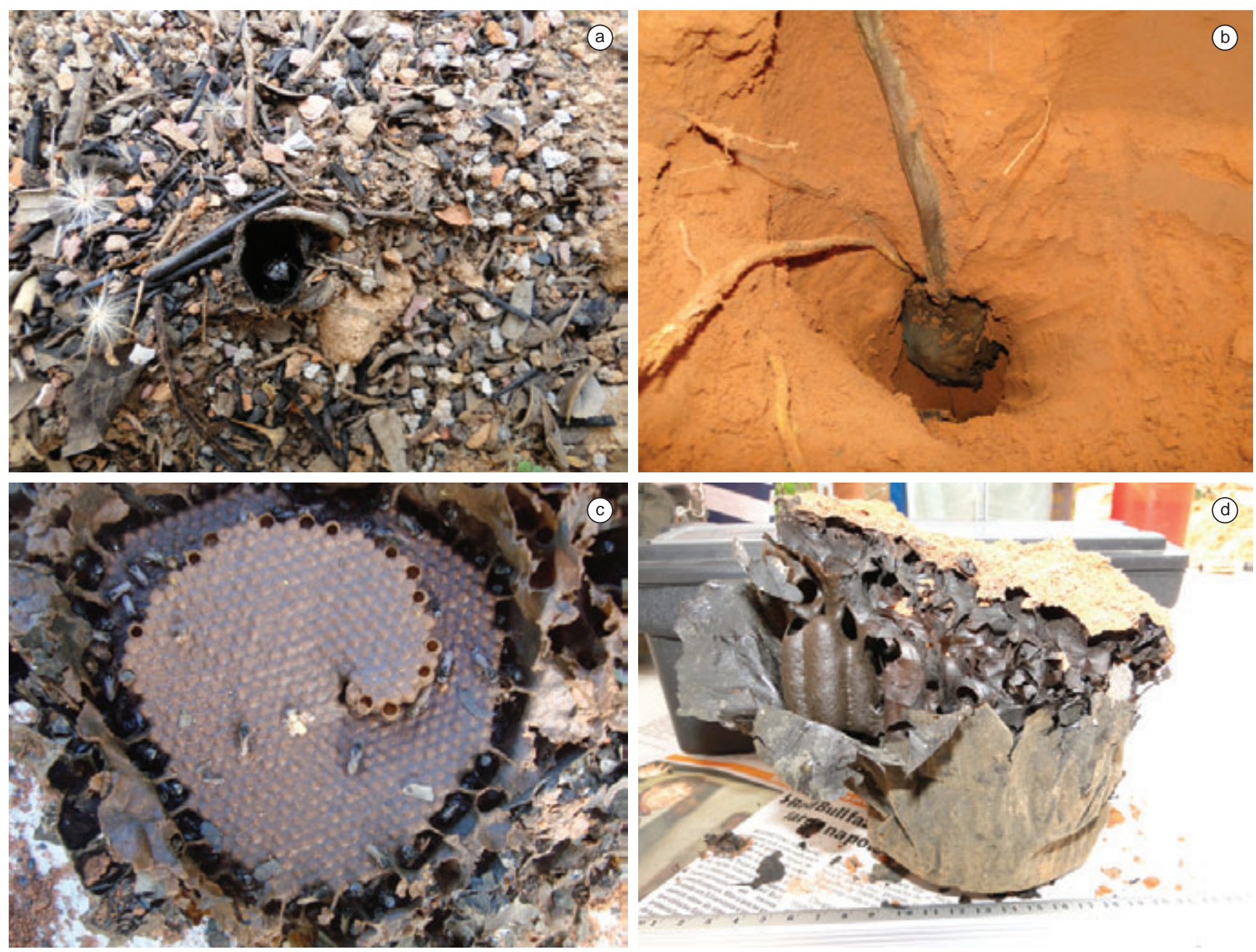

Figure 1. Nest architecture of Geotrigona subterranea: (a) nest entrance; (b) general view of the nest in the underground cavity, showing the entrance tube; (c) brood combs with spiral shape; (d) view of the nest showing food pots and the outer involucrum.

arthropods. The ground next to the garbage was very dry and its texture was loose and light, even if the surrounding soil was moist.

\subsection{Population}

The estimated population, including young and adult individuals, varied from 2,726 to 11,074 , with an average value of 7,485 bees. We did not observe virgin queens and males during the period when the nests were collected, since swarming was not taking place.

\subsection{Inquilines}

We observed several arthropods, especially in the region where the bees deposited the garbage. There were beetles (Insecta: Coleoptera), earwigs (Insecta: Dermaptera), woodlice (Malacostraca: Isopoda), myriapods (Quilopoda), pseudoscorpions (Pseudoescorpiones), and mites (Acarina: Acari). Although these arthropods have different feeding habits, they all find their food in sources of decomposing organic matter.

\section{Discussion}

Species that build underground nests are relatively rare among stingless bees (Wille 1966). According to Schwarz (1948) and Camargo \& Moure (1996) all species of the genus Geotrigona have subterranean nests. Nogueira-Neto \& Sakagami (1966) studied three nests of Geotrigona mombuca and observed a preference for abandoned chambers built by Atta leafcutter ants.

The presence of nests in soils with different physical properties suggests that soil type did not affect chamber choice. NogueiraNeto \& Sakagami (1966) also observed that soil differences did not influence nesting in G. mombuca.

Despite the location of the nests in areas with dense vegetation, the preference for nesting in open areas allows high light incidence, which directly affects the external activity of bees.

The detritus adorning the entrance has the function to guide foraging bees to the nest (Nogueira-Neto \& Sakagami 1966, Camargo \& Moure 1996, Lacerda et al. 1998). It was observed that debris deposited around the entrance can help protect the colony. Large amounts of sticks deposited during periods of high rainfall prevent germination and development of weeds that may block the nest entrance. The entrance is not closed at night, as observed in other bee species (Wille 1983).

Nogueira-Neto \& Sakagami (1966) studied three nests of G. mombuca, and observed that the chamber walls were lined with a cerumen layer. However, Camargo \& Moure (1996) did not observe this characteristic in other two species of the same genus: G. subterranea, focus of the present study, and G. mattogrossensis. We did not observe coating on chamber walls either.

The presence of honey and pollen in the same pot can be explained by a lack of storage space in peak periods of storage. 
In the brood area, multiple involucrum layers have the function of keeping the temperature constant within the nest and retaining the heat produced by the brood metabolism (Wille 1983). Alves et al. (2003) observed that this structure was, in most cases, absent in Trigona fulviventris, because the soil allows low temperature variation. São-Thiago et al. (2009) observed this structure surrounding the brood area in five nests of Melipona quinquefasciata.

Some species of stingless bees build no involucrum. It usually occurs in bee groups that build brood cell clusters. However, even in species that build compact honeycombs, sometimes the shell is reduced or absent (Nogueira-Neto 1997). Kerr et al. (1967) stated that the involucrum may be optional, and its construction is related to external temperature conditions. However, Camargo (1970) noted that the lack of an involucrum in some species is not determined by climate, but rather by the nesting site, which was also observed in Scaura latitarsis.

Although temperature variation is low in the soil, soil temperature at the average depth where the nests are built $\left(24.9 \pm 0.25{ }^{\circ} \mathrm{C}\right)$ was lower than the temperature of the soil in the brood region $\left(28.7 \pm 1.12{ }^{\circ} \mathrm{C}\right)$. This may be explained the presence of several involucrum layers in the brood region. It is possible that waste decomposition inside the colony generates heat, helping maintain the nest temperature constant.

The non-permeability of the soil in the waste area may be due to the presence of high amounts of organic matter from the decomposition of waste materials. According to Silva (2008) high levels of organic matter reflect a high hydrophobic characteristic of the soil. The hydrophilic portion of the material is oriented toward the interior of the aggregate, whereas the hydrophobic portion is directed to the outer surface, forming a water-repellent layer.

The pattern of cell construction resembles that of other species. In G. mombuca, Lacerda et al. (1991) and Lacerda \& Zucchi (1999) found out that brood cell construction is successive. According to these authors, the provision of the cells is synchronized.

The presence of a drainage channel was observed by Portugal-Araújo (1963) in two African species of stingless bees (Plebeiella lendliana and Meliplebeia beccarii), in which the channel ends in a sandy region located on the bottom of the nest. The same structure was described for Nogueirapis mirandula and Tetragonisca buchwaldi in Costa Rica (Wille 1964, 1966); and for Partamona testacea and Trigona recursa (Camargo 1970). The observations of Nogueira-Neto \& Sakagami (1966) are consistent with the present study since the authors did not find this structure in another species of the genus: G. mombuca, whose nest is similar to that of $G$. subterranea. The nests found in abandoned chambers built by leafcutter ants had other cavities, which were connected to each other by channels located near the nest cavity. Nogueira-Neto \& Sakagami (1966) believe that these cavities play a role in moisture drainage, in case of overflow.

In general, bee colonies with a single entrance tube have any mechanism of ventilation (Moritz \& Crewe 1988). According to Nogueira-Neto \& Sakagami (1966) ventilation may be made through air spaces in the soil.

The characteristics of nest architecture in G. mombuca described by Nogueira-Neto \& Sakagami (1966) are similar to those in G. subterranea observed in the present study. Camargo \& Moure (1996), studying one nest of G. mattogrossensis, obtained similar results.

Camargo \& Moure (1996) described briefly two nests of G. subterranea, showing characteristics similar to those found in the present study. According to these authors, the nest of $G$. subterranea differs a little from that of other species of Geotrigona, in terms of architecture.

\section{Conclusion}

Nest architecture in G. subterranea is similar to other species of the genus, as this bee species builds its nests in several types of underground cavities.

\section{Acknowledgments}

To Dr. Sílvia R. M. Pedro of the Department of Biology of the FFCLRP-USP for identification of the bee species. At the Conselho Nacional de Desenvolvimento Científico e Tecnológico (CNPQ) for the studentship to CALC (Proc. 30327/2010-4).

\section{References}

AIDAR, D.S. 1996. A mandaçaia - biologia de abelhas, manejo e multiplicação artificial de colônias de Melipona quadrifasciata Lep. (Hymenoptera, Apidae, Meliponinae). Sociedade Brasileira de Genética 04.

ALVES, R.M.O., CARVALHO, C.A.L. \& SOUZA, B.A. 2003. Arquitetura do ninho e aspectos bioecológicos de Trigona fulviventris fulviventris Guerin, 1853 (Hymenoptera: Apidae). Magistra 15:97-100.

CAMARGO, J.M.F. \& MOURE, J.S. 1996. Meliponini neotropicais: o gênero Geotrigona Moure. Arq. Zool. 33(3):95-161.

CAMARGO, J.M.F. 1970. Ninhos e biologia de algumas espécies de Meliponideos (Hymenoptera: Apidae) da região de Porto Velho, Território de Rondônia, Brasil. Rev. Biol. Trop. 16:207-239.

CAMARGO, J.M. F. \& PEDRO, S.R.M. 2012. Meliponini Lepeletier, 1836. In Catalogue of Bees (Hymenoptera, Apoidea) in the Neotropical Region (J.S. Moure, D. Urban, \& G.A.R. Melo, orgs.). Online version. http:// www.moure.cria.org.br/catalogue (último acesso em 28/09/2012).

CAMPOS, L.A.O. 1987. Abelhas indígenas sem ferrão: o que são? Info. Agrop. 13(147).

GONZALEZ, V.H. \& ENGEL, M.S. 2012. A new species of Geotrigona Moure from the Caribbean coast of Colombia (Hymenoptera, Apidae). ZooKeys 172:77-87. http://dx.doi.org/10.3897/zookeys.172.2735

GONZALEZ, V.H. \& SEPÚLVEDA, P. 2007. Una especie nueva de Geotrigona (Hymenoptera: Apidae, Meliponini), con comentarios sobre el género en Colombia. Acta Biol. Colomb. 12S:103-108.

KERR, W.E., CARVALHO, G.A. \& NASCIMENTO, V.A. 1996. Abelha uruçu: biologia, manejo e conservação. Fundação Acangaú, Belo Horizonte.

KERR, W.E., SAKAGAMI, S.F., ZUCCHI, R., ARAÚJO, V.P. \& CAMARGO, J.M.F. 1967. Observações sobre a arquitetura dos ninhos e comportamento de algumas espécies de abelhas sem ferrão das vizinhanças de Manaus, Amazonas (Hymenoptera, Apoidea). Atas Simp. Biota Amazôn. 5(Zool.):255-309.

LACERDA, L.M., ZUCCHI, R. \& ZUCOLOTO, F.S. 1991. Colony condition and bionomic alterations in Geotrigona inusitata (Apidae, Meliponini). Acta Biol. Par. 20(1,2,3,4):109-123.

LACERDA, L.M. \& ZUCCHI, R. 1999. Behavioral Alterations and Related Aspects in Queenless Colonies of Geotrigona mombuca (Hymenoptera, Apidae, Meliponinae). Sociobiology 33(3):277-288.

LACERDA, L.M., ZUCCHI, R. \& SAKAGAMI, S.F. 1998. Oviposition behavior of the stingless bees, XXV. Ethological relationships of Geotrigona mombuca to other stingless bees taxa (Insecta: Hymenoptera; Apidae, Meliponinae). Nat. Hist. Bull. Ibaraki Univ. 2:263-276.

MICHENER, C.D. 2007. The bees of the world. 2. ed. Jonhs Hopkins University Press, Baltimore.

MORITZ, R.F.A. \& CREWE, R.M. 1988. Air ventilation in nests of two African stingless bees Trigona denoiti and trigona gribodoi. Experientia 44:1024-1027. http://dx.doi.org/10.1007/BF01939912

NOGUEIRA-NETO, P. 1997. Vida e criação de abelhas indígenas sem ferrão. Editora Nogueirapis, São Paulo.

NOGUEIRA-NETO, P. \& SAKAGAMI, S.F. 1966. Nest structure of a subterranean stingless bee Geotrigona mombuca Smith (Meliponinae, Apidae, Hymenoptera). An. Acad. Bras. Ciênc. 38(1):187-194. 
Barbosa, F.M. et al.

PORTUGAL-ARAÚJO, V. 1963. Subterranean nests of two African stingless bees (Hymenoptera: Apidae ). J. N. Y. Ent. Soc. 71:130-141.

RASMUSSEN, C. \& CAMARGO, J.M. 2008. A molecular phylogeny and the evolution of nest architeture and behavior in Trigona s.s. (Hymenoptera: Apidae: Meliponini). Apidologie 39:102-118. http://dx.doi.org/10.1051/ apido:2007051

ROUBIK, D.W. 2006. Stingless bee nesting biology. Apidologie 37:124-143. http://dx.doi.org/10.1051/apido:2006026

SÃO-THIAGO, P.S., SABINO, W., SILVEIRA, M.A., BASTOS, E.M.A.F. \& ANTONINI, Y. 2009. Internal structure of Melipona quinquefasciata Lepeletier nests in a Cerrado area, Minas Gerais, Brazil. In Anais do III Congresso Latino Americano de Ecologia. São Lourenço.

SCHWARZ, H.F. 1948. Stingless bees (Meliponidae) of the western hemisphere. Lestrimellita and the following subgenera of Trigona: Trigona, Paratrigona, Schwarziana, Parapartamona, Cephalotrigona, Oxitrigona, Scaura and Mourella. Bull. Am. Mus. Nat. Hist. 90:1-546.

SILVA, I.R. 2008. Constituição, propriedades e classificação de solos. Viçosa.
SILVEIRA, F.A., MELO, G.A.R. \& ALMEIDA, E.A.B. 2002. Abelhas Brasileiras: Sistemática e Identificação. Fundação Araucária, Belo Horizonte.

SOUZA, B.A., CARVALHO, C.A.L. \& ALVES, R.M.O. 2008. Notas sobre a bionomia de Melipona asilvai (Apidae: Meliponini) como subsídio à sua criação racional. Arch. Zootec. 57:53-62.

WILLE, A. 1964. Notes on a primitive stingless bees, Trigona (Nogueirapis) mirandula. Rev. Biol. Trop. 12(1):117-151.

WILLE, A. 1966. Notes on two species of ground nesting stingless bees (Trigona mirandula and T. buchwaldi) from the pacific rain forest of Costa Rica. Rev. Biol. Trop. 14(2):251-277.

WILLE, A. 1983. Biology of the stingless bees. Ann. Rev. Entomol. 28:41-64. http://dx.doi.org/10.1146/annurev.en.28.010183.000353

WILLE, A. \& MICHENER, C.D. 1973. The nest architeture of stingless bees with special reference to those of Costa Rica (Hymenoptera: Apidae). Rev. Biol. Trop. 21:1-278. 